\title{
Riwayat asupan energi dan protein yang kurang bukan faktor risiko stunting pada anak usia 6-23 bulan
}

\author{
Low energy and protein intakes were not risk factors of stunting in children 6-23 months
}

Rahmaniah ${ }^{1}$, Emy Huriyati ${ }^{2}$, Winda Irwanti ${ }^{3}$

\begin{abstract}
Background: Stunting was a chronic nutrition problem that still be a concern in the developing nations include Indonesia. The direct cause of stunting was infectious disease and inadequate food intake such as energy and protein deficiency. In Indonesia in 2010, the prevalence of stunting was 35.7\%, in Yogyakarta as much as 22.5\%, in Bantul District in 2012 was $18.08 \%$ and in Sedayu Subdistrict was $30.51 \%$.

Objectives: To know the history of energy and protein intake as the risk factors of stunting in children of 6-23 months.

Methods: This was an observational study with case-control design. The population were children aged 6-23 months who lived in Sedayu Subdistrict, Bantul. The measurement energy and protein intake used a semi-quantitative food frequency questionnaire and determination of stunting used the WHO standard anthro 2005. Samples were selected by total sampling approachment. Data was analyzed by chi-square and logistic regression test.

Results: The result of bivariate analysis showed that birth weight and maternal height had significant association with stunting $(p<0.05)$. While energy and protein intake did not associated with stunting. However, there was a tendency that children with less energy and protein intake had higher risk of stunting. Multivariate analysis showed that maternal height was the dominant variable effect on the prevalence of stunting (OR=2.06).

Conclusions: Low energy and protein intakes were not risk factors of stunting in children 6-23 months. Maternal height was dominant variable that influenced the stunting incidence.
\end{abstract}

KEYWORDS: energy intake, protein intake, stunting, child

\begin{abstract}
ABSTRAK
Latar belakang: Stunting merupakan masalah gizi kronis yang masih menjadi perhatian di negara berkembang termasuk Indonesia. Penyebab langsung stunting adalah penyakit infeksi dan asupan makanan yang tidak memadai seperti kurang energi dan protein. Di Indonesia pada tahun 2010 prevalensi stunting sebanyak 35,7\%, di Daerah Istimewa Yogyakarta sebanyak 22,5\%, di Kabupaten Bantul tahun 2012 sebesar 18,08\% dan Kecamatan Sedayu 30,51\%.

Tujuan: Untuk mengetahui riwayat asupan energi dan protein sebagai faktor risiko stunting pada anak usia 6-23 bulan.

Metode: Jenis penelitian observasional dengan rancangan case-control. Populasinya seluruh anak usia 6-23 bulan yang ada di wilayah Kecamatan Sedayu Kabupaten Bantul. Pengukuran asupan energi dan protein dengan menggunakan semi-quantitative food frequency questionnaire dan penentuan stunting dengan menggunakan baku standar WHO anthro 2005. Cara pengambilan sampel adalah dengan total sampling. Analisis data menggunakan uji chi-square dan regresi logistik.
\end{abstract}

\footnotetext{
1 Pasca Sarjana IImu Kesehatan Masyarakat Minat Gizi dan Kesehatan Fakultas Kedokteran Universitas Gadjah Mada, Jl. Farmako, Sekip Utara Yogyakarta 55281, e-mail: niabdr@gmail.com

2 Program Studi Gizi dan Kesehatan, Fakultas Kedokteran Universitas Gadjah Mada, JI Farmako, Sekip Utara, Yogyakarta 55281, e-mail: emyhuriyati@yahoo.com

${ }^{3}$ Program Studi S1 IImu Gizi, STIKES Alma Ata Yogyakarta, Jl. Ring Road Barat Daya No 1, Yogyakarta 55183, e-mail: winda_irwanti@ yahoo.co.id
} 


\begin{abstract}
Hasil: Berat bayi lahir dan tinggi badan ibu menunjukkan hubungan signifikan dengan kejadian stunting $(p<0,05)$, sedangkan riwayat asupan energi dan protein tidak berhubungan dengan stunting $(p>0,05)$. Secara multivariat, tinggi badan ibu merupakan variabel yang dominan berpengaruh terhadap stunting $(O R=2,06)$.

Kesimpulan: Asupan energi dan protein yang kurang bukan merupakan faktor risiko kejadian stunting pada anak usia 6-23 bulan. Tinggi badan ibu merupakan variabel yang dominan berpengaruh terhadap kejadian stunting.
\end{abstract}

KATA KUNCI: asupan energi, asupan protein, stunting, anak

\section{PENDAHULUAN}

Masalah gizi masih menjadi perhatian di negara berkembang termasuk Indonesia. Hal ini dapat terlihat di dalam rumusan Millennium Development Goals (MDGs), goal pertama yang menggunakan indikator prevalensi balita kurang gizi (BKG) dan proporsi penduduk yang berada di bawah garis konsumsi minimum $2.100 \mathrm{kkal} /$ kapita/hari (1). Kekurangan gizi berupa energi protein dapat bersifat akut (wasting), bersifat kronis (stunting), dan bersifat akut dan kronis (underweight) (2). Kurang gizi kronis (stunting) dapat berisiko terhadap penyakit dan kematian, mempengaruhi masalah kognitif, prestasi sekolah, produktivitas ekonomi di masa dewasa, dan hasil reproduksi ibu $(3,4)$.

Stunting merupakan gangguan pertumbuhan linier yang diunjukkan dengan tinggi badan menurut umur $<-2$ standar deviasi dari median tinggi badan menurut umur berdasarkan standar populasi yang dijadikan referensi (3). Stunting pada anak usia 2 tahun berawal dari ibu hamil kurang gizi (5). Stunting juga disebabkan praktik pemberian makan yang buruk, kualitas makanan tidak baik, serta infeksi. Selain itu, pelayanan kesehatan yang optimal, akses terhadap air bersih, dan sanitasi juga berpengaruh (3). Secara umum penyebab utama stunting adalah retardasi pertumbuhan intrauteri, asupan gizi yang tidak mencukupi, dan penyakit infeksi selama awal kehidupan (6).

Kurang energi dan protein berpengaruh besar terhadap status gizi anak (7). Hasil penelitian di Afrika Utara menyatakan bahwa tingginya persentase stunting menunjukkan terjadinya defisiensi asupan gizi anak berupa energi dan beberapa asupan zat gizi mikro (8). Kepatuhan waktu pemberian makanan pendamping ASI (MP-
ASI) juga berpengaruh terhadap stunting. Anak yang diberi MP-ASI sebelum 6 bulan mengalami berisiko lebih besar stunting (9). Keragaman makanan juga diperlukan agar asupan energi dan nutrisi meningkat. Keragaman makanan secara bermakna dikaitkan dengan berat badan menurut umur (BB/U), panjang badan menurut umur (PB/U) dan berat badan menurut panjang badan (BB/PB) (10).

Secara umum, di Indonesia masih terdapat rumah tangga yang mengonsumsi energi dan protein di bawah dari yang dianjurkan yaitu sebanyak $40-50 \%$ rumah tangga mengonsumsi energi kurang dari $1.500 \mathrm{kkal}$ dan $25 \%$ rumah tangga mengonsumsi protein kurang dari $70 \%$ (11). Berdasarkan data riset kesehatan dasar tahun 2010, penduduk Indonesia yang mengonsumsi energi dan protein di bawah kebutuhan minimal masing-masing 40,7\% dan 37\%. Sementara itu, khusus di Provinsi Daerah Istimewa Yogyakarta (DIY) jumlah penduduk yang mengonsumsi energi dan protein di bawah kebutuhan minimal secara berturut-turut sebesar $40,9 \%$ dan $43,7 \%$ (12).

Berdasarkan hasil penelitian pada balita di masyarakat Suku Naulu Maluku diketahui bahwa terdapat hubungan bermakna antara asupan zat gizi (energi dan protein) dengan status gizi berdasarkan indeks BB/U dan TB/U (13). Hal ini sejalan dengan penelitian pada anak umur 6-18 bulan di panti sosial anak se-DKI dan Tangerang yang diketahui bahwa anak dengan asupan energi kurang mempunyai risiko 1,7 kali menjadi gizi kurang pada indeks TB/U dan 2,2 kali pada indeks BB/U (14). Hasil penelitian pada anak umur 6-24 bulan di Soc Son Vietnam juga mengemukakan bahwa konsumsi protein berhubungan dengan stunting (15). 
Prevalensi stunting di seluruh dunia pada tahun 2020 diperkirakan akan semakin mengalami penurunan (16). Di Indonesia, prevalensi pendek pada balita secara nasional sebesar $35,7 \%$ dan di Provinsi DIY sebesar 22,5\% (12). Prevalensi stunting di DIY masih merupakan masalah jika dibandingkan dengan batas non public health problem WHO sebesar 20\%. Di Kabupaten Bantul, prevalensi stunting di tahun 2012 pada anak usia 6-24 bulan sebesar $18,08 \%$, tertinggi kedua di DIY, sedangkan di Kecamatan Sedayu sebesar $30,51 \%(17)$. Berdasarkan tujuan penelitian ini untuk mengetahui riwayat asupan energi dan protein sebagai faktor risiko stunting pada anak usia 6-23 bulan di Kecamatan Sedayu, Kabupaten Bantul Yogyakarta.

\section{BAHAN DAN METODE}

Jenis penelitian ini adalah observasional dengan desain case-control yang dilakukan di Kecamatan Sedayu Kabupaten Bantul pada bulan April hingga Juni 2014. Penelitian ini merupakan bagian dari penelitian yang berjudul "Status Gizi lbu Hamil dan Baduta di Kecamatan Sedayu Kabupaten Bantul D.I Yogyakarta" yang dilaksanakan oleh Alma Ata Center For Healthy Life and Food (ACHEAF) Yogyakarta. Subjek penelitian anak usia 6-23 bulan yang memenuhi kriteria inklusi dan eksklusi. Kriteria inklusi kasus dan kontrol adalah anak usia 6-23 bulan, untuk kasus adalah yang berstatus gizi stunting dan kontrol berstatus gizi normal. Apabila dalam suatu keluarga memiliki lebih dari satu anak baduta, maka diambil anak yang lebih tua, ibu anak memiliki buku kesehatan ibu dan anak, ibu anak bersedia menjadi responden penelitian dengan menandatangani informed consent. Kriteria eksklusi kasus dan kontrol yaitu anak cacat fisik seperti tidak punya kaki atau kaki tidak bisa diluruskan. Teknik pengambilan sampel menggunakan total sampling dengan jumlah sampel kasus 126 dan kontrol 126 anak dengan matching pada umur.

Variabel terikat pada penelitian ini adalah stunting pada anak usia 6-23 bulan. Variabel bebas adalah riwayat asupan energi dan protein dan variabel pengganggu yaitu status menyusu, lingkar lengan atas (LILA) ibu, berat bayi lahir, tinggi badan ibu dan ayah, pendapatan keluarga, dan riwayat penyakit infeksi. Data riwayat asupan energi dan protein diperoleh dengan menggunakan semi-quantitative food frequency questionnaire (SQ-FFQ) yang sebelumnya telah divalidasi jenis bahan makanan terhadap 30 responden, sehingga dihasilkan 114 jenis bahan makanan dari 146 jenis bahan makanan. Pengumpulan data riwayat asupan energi dan protein dilakukan sejak bulan April hingga Juni tahun 2014. Ukuran/porsi makan diestimasi menggunakan food model dan buku foto makanan yang digunakan oleh Kemenkes RI saat survei diet total tahun 2014. Data panjang badan anak dikumpulkan menggunakan lengthboard dengan ketelitian $0,1 \mathrm{~cm}$ dan pengukuran tinggi badan ibu serta ayah menggunakan microtoise. Data LILA dan berat badan lahir anak diperoleh dari buku kesehatan ibu dan anak serta buku kohort. Data status menyusu dan pendapatan keluarga diperoleh dari kuesioner. Data riwayat penyakit infeksi diperoleh dari kuesioner yang diadopsi dari kuesioner Indonesian demographic and health survey 2012.

Analisis univariat digunakan untuk mengetahui distribusi karakteristik subjek penelitian, sedangkan hubungan antarvariabel diketahui dari uji chisquare dan untuk mengetahui variabel yang paling berpengaruh digunakan uji regresi logistik. Penelitian ini sudah mendapat surat kelayakan etik dari Komite Etik Penelitian Kedokteran dan Kesehatan Fakultas Kedokteran Universitas Gadjah Mada Yogyakarta dengan nomor Ref: KE/FK/382/EC tahun 2014.

\section{HASIL}

Hasil penelitian menunjukkan bahwa sebagian besar subjek berjenis kelamin laki-laki (55,56\%) dengan kasus dan kontrol masing-masing sebanyak 126 anak. Anak yang masih diberi ASI sebanyak $72,62 \%$. Sebagian besar anak memiliki riwayat asupan energi dan protein yang cukup masingmasing sebesar $81,75 \%$ dan $89,68 \%$. Sebagian besar anak lahir dengan berat badan lahir normal $(92,46 \%)$ dan ibu dari subjek memiliki LILA yang normal $(76,98 \%)$. Sebagian besar anak memiliki tinggi badan ibu dan ayah normal masing-masing 
sebesar $68,65 \%$ dan $66,67 \%$. Untuk pendapatan keluarga, persentase terbanyak yaitu yang memiliki pendapatan cukup $(66,27 \%)$ dan untuk variabel riwayat penyakit infeksi mayoritas anak pernah mengalami penyakit infeksi $(60,32 \%)$ (Tabel 1).

Tabel 1. Distribusi karakteristik subjek dan responden

\begin{tabular}{|c|c|c|}
\hline Variabel & $n=252$ & $\%$ \\
\hline \multicolumn{3}{|l|}{ Status gizi } \\
\hline Stunting & 126 & 50 \\
\hline Normal & 126 & 50 \\
\hline \multicolumn{3}{|l|}{ Jenis kelamin } \\
\hline Laki-laki & 140 & 55,56 \\
\hline Perempuan & 112 & 44,44 \\
\hline \multicolumn{3}{|l|}{ Status menyusu } \\
\hline Tidak diberikan ASI & 69 & 27,38 \\
\hline Masih diberikan ASI & 183 & 72,62 \\
\hline \multicolumn{3}{|l|}{ Berat badan lahir baduta } \\
\hline BBLR & 19 & 7,54 \\
\hline Normal & 233 & 92,46 \\
\hline \multicolumn{3}{|l|}{ Riwayat asupan energi } \\
\hline Kurang & 46 & 18,25 \\
\hline Cukup & 206 & 81,75 \\
\hline \multicolumn{3}{|l|}{ Riwayat asupan protein } \\
\hline Kurang & 26 & 10,32 \\
\hline Cukup & 226 & 89,68 \\
\hline \multicolumn{3}{|l|}{ Lingkar lengan atas ibu } \\
\hline Kurang & 58 & 23,02 \\
\hline Normal & 194 & 76,98 \\
\hline \multicolumn{3}{|l|}{ Tinggi badan ibu } \\
\hline Pendek & 79 & 31,35 \\
\hline Normal & 173 & 68,65 \\
\hline \multicolumn{3}{|l|}{ Tinggi badan ayah } \\
\hline Pendek & 84 & 33,33 \\
\hline Normal & 168 & 66,67 \\
\hline \multicolumn{3}{|l|}{ Pendapatan keluarga } \\
\hline Rendah & 85 & 33,73 \\
\hline Cukup & 167 & 66,27 \\
\hline \multicolumn{3}{|l|}{ Riwayat penyakit infeksi } \\
\hline Ada infeksi & 152 & 60,32 \\
\hline Tidak ada infeksi & 100 & 39,69 \\
\hline
\end{tabular}

Hasil analisis chi-square (Tabel 2) diperoleh bahwa tidak terdapat hubungan yang signifikan antara asupan energi dan protein $(p>0,05)$. Namun demikian, terdapat kecenderungan bahwa anak yang mengonsumsi energi dan protein yang kurang berisiko lebih tinggi terhadap stunting dibandingkan anak yang mengonsumsi energi dan protein yang cukup $(O R=1,24$ dan $O R=1,41)$. Rata-rata asupan energi dan protein anak pada kelompok stunting lebih rendah dibanding asupan energi dan protein pada kelompok anak yang berstatus gizi normal (Tabel 3).

Hasil analisis chi-square (Tabel 4) menunjukkan bahwa tidak terdapat hubungan yang signifikan antara jenis kelamin, status menyusu, lingkar lengan atas ibu, penyakit infeksi, tinggi badan ayah, dan pendapatan keluarga terhadap stunting $(p>0,05)$. Terdapat hubungan yang signifikan antara berat bayi lahir dan tinggi badan ibu dengan kejadian stunting $(p<0,05)$. Anak yang memiliki berat lahir rendah berisiko untuk stunting 3,02 kali lebih besar dibandingkan dengan anak yang lahir dengan berat lahir normal dan anak yang terlahir dari ibu yang memiliki tinggi badan yang berkategori pendek berisiko stunting 2,03 kali lebih besar dibandingkan dengan anak yang terlahir dari ibu yang memiliki tinggi badan normal.

Tabel 3. Rata-rata asupan energi dan protein

\begin{tabular}{lcc}
\hline \multicolumn{1}{c}{ Asupan zat gizi } & $\begin{array}{c}\text { Stunting } \\
\text { Mean } \pm \text { SD }\end{array}$ & $\begin{array}{c}\text { Normal } \\
\text { Mean } \pm \text { SD }\end{array}$ \\
\hline Asupan energi (\% AKG) & $89,09 \pm 23,33$ & $91,13 \pm 22,68$ \\
Asupan energi (kkal) & $857,70 \pm 110,36$ & $919,03 \pm 126,91$ \\
Asupan protein (\% AKG) & $122,79 \pm 32,37$ & $129,87 \pm 34,46$ \\
Asupan protein $(\mathrm{g})$ & $20,08 \pm 2,15$ & $21,51 \pm 2,56$ \\
\hline
\end{tabular}

Tabel 2. Analisis bivariat variabel bebas terhadap kejadian stunting

\begin{tabular}{|c|c|c|c|c|c|c|}
\hline \multirow{3}{*}{ Variabel } & \multicolumn{4}{|c|}{ Status gizi } & \multirow{3}{*}{$\mathbf{p}$} & \multirow{3}{*}{$\begin{array}{c}\text { OR } \\
(95 \% \mathrm{Cl})\end{array}$} \\
\hline & \multicolumn{2}{|c|}{ Stunting } & \multicolumn{2}{|c|}{ Normal } & & \\
\hline & $\mathbf{n}$ & $\%$ & $\mathbf{n}$ & $\%$ & & \\
\hline \multicolumn{7}{|c|}{ Riwayat asupan energi } \\
\hline Kurang & 25 & 19,84 & 21 & 16,67 & \multirow{2}{*}{0,51} & 1,24 \\
\hline Cukup & 101 & 80,16 & 105 & 83,33 & & $0,62-2,48$ \\
\hline \multicolumn{7}{|c|}{ Riwayat asupan protein } \\
\hline Kurang & 15 & 11,90 & 11 & 8,73 & \multirow{2}{*}{0,40} & 1,41 \\
\hline Cukup & 111 & 88,10 & 115 & 91,27 & & $0,58-3,56$ \\
\hline
\end{tabular}


Tabel 4. Analisis bivariat variabel pengganggu terhadap kejadian stunting

\begin{tabular}{|c|c|c|c|c|c|c|}
\hline \multirow{3}{*}{ Variabel } & \multicolumn{4}{|c|}{ Status gizi } & \multirow{3}{*}{$\mathbf{p}$} & \multirow{3}{*}{$\begin{array}{c}\text { OR } \\
(95 \% \mathrm{Cl})\end{array}$} \\
\hline & \multicolumn{2}{|c|}{ Stunting } & \multicolumn{2}{|c|}{ Normal } & & \\
\hline & $\mathbf{n}$ & $\%$ & $\mathbf{n}$ & $\%$ & & \\
\hline \multicolumn{7}{|l|}{ Jenis kelamin } \\
\hline Laki-laki & 66 & 52,38 & 74 & 58,73 & \multirow{2}{*}{0,31} & \multirow{2}{*}{$\begin{array}{c}0,77 \\
(0,46-1,31)\end{array}$} \\
\hline Perempuan & 60 & 47,62 & 52 & 41,27 & & \\
\hline \multicolumn{7}{|l|}{ Status menyusu } \\
\hline Tidak diberikan ASI & 29 & 23,02 & 40 & 31,75 & \multirow{2}{*}{0,12} & \multirow{2}{*}{$\begin{array}{c}0,64 \\
(0,35-1,17)\end{array}$} \\
\hline Masih diberikan ASI & 97 & 76,98 & 86 & 68,25 & & \\
\hline \multicolumn{7}{|l|}{ Lingkar lengan atas ibu } \\
\hline Kurang & 25 & 19,84 & 33 & 26,19 & \multirow{2}{*}{0,23} & \multirow{2}{*}{$\begin{array}{c}0,69 \\
(0,37-1,31)\end{array}$} \\
\hline Normal & 101 & 80,16 & 93 & 73,81 & & \\
\hline \multicolumn{7}{|l|}{ Berat bayi lahir } \\
\hline BBLR & 14 & 11,11 & 5 & 3,97 & \multirow{2}{*}{$0,03^{*}$} & \multirow{2}{*}{$\begin{array}{c}3,02 \\
(0,99-11,04)\end{array}$} \\
\hline Normal & 112 & 88,89 & 121 & 96,03 & & \\
\hline \multicolumn{7}{|l|}{ Penyakit infeksi } \\
\hline Ada infeksi & 78 & 61,90 & 74 & 58,73 & \multirow{2}{*}{0,61} & \multirow{2}{*}{$\begin{array}{c}1,14 \\
(0,67-1,95)\end{array}$} \\
\hline Tidak ada infeksi & 48 & 38,10 & 52 & 41,27 & & \\
\hline \multicolumn{7}{|l|}{ Tinggi badan ibu } \\
\hline Pendek & 49 & 38,89 & 30 & 23,81 & \multirow{2}{*}{$0,01^{*}$} & \multirow{2}{*}{$\begin{array}{c}2,03 \\
(1,14-3,65)\end{array}$} \\
\hline Normal & 77 & 61,11 & 96 & 76,19 & & \\
\hline \multicolumn{7}{|l|}{ Tinggi badan ayah } \\
\hline Pendek & 46 & 36,51 & 38 & 30,16 & \multirow{2}{*}{0,29} & \multirow{2}{*}{$\begin{array}{c}1,33 \\
(0,76-2,33)\end{array}$} \\
\hline Normal & 80 & 63,49 & 88 & 69,84 & & \\
\hline \multicolumn{7}{|l|}{ Pendapatan keluarga } \\
\hline Rendah & 45 & 35,71 & 39 & 30,95 & \multirow{2}{*}{0,42} & \multirow{2}{*}{$\begin{array}{c}0,81 \\
(0,46-1,41) \\
\end{array}$} \\
\hline Cukup & 81 & 64,29 & 87 & 69,05 & & \\
\hline
\end{tabular}

* Signifikan $(p<0,05)$

\section{Faktor yang dominan berpengaruh terhadap kejadian stunting}

Analisis regresi logistik (Tabel 5) bertujuan untuk menentukan variabel yang paling berpengaruh terhadap kejadian stunting. Model 1 menunjukkan variabel asupan energi dan protein sebelum dikontrol dengan variabel luar yang dapat memprediksi kejadian stunting $(0,21 \%)$. Meskipun tidak terdapat hubungan antara asupan energi dan protein, terdapat kecenderungan bahwa anak yang kekurangan energi dan protein lebih berisiko terhadap stunting $(\mathrm{OR}=1,09$ dan $\mathrm{OR}=1,31)$. Model 2 menunjukkan besarnya pengaruh LILA terhadap nilai $R^{2}$ yang meningkat menjadi 0,68 . Hal ini berarti bahwa riwayat asupan energi dan protein dengan mengontrol variabel LILA ibu saat hamil dapat memprediksi kejadian stunting senilai $0,68 \%$.

Model 3 menunjukkan bahwa riwayat asupan energi dan protein dengan mengontrol variabel status menyusu dapat memprediksi kejadian stunting $(0,81 \%)$. Model 4 dan 5 menunjukkan besarnya pengaruh berat badan lahir dan tinggi badan (TB) ibu setelah diikutkan dalam analisis dengan nilai $R^{2}$ meningkat masing-masing sebesar 1,56 dan 2,11. Hal ini berarti bahwa riwayat asupan energi dan protein dengan mengontrol berat badan lahir dan TB ibu dapat memprediksi kejadian stunting $1,56 \%$ dan $2,11 \%$.

Model 6 menunjukkan bahwa riwayat asupan energi dan protein dengan mengontrol LILA, status menyusu, berat bayi lahir, dan TB ibu dapat memprediksi kejadian stunting $(4,44 \%)$. Variabel yang berhubungan $(p<0,05)$ dan paling berpengaruh adalah TB ibu (95\% Cl:1,17-3,63 dan $\mathrm{OR}=2,06$ ). Tidak ada hubungan antara riwayat asupan energi dan protein setelah dikendalikan oleh variabel LILA, status menyusu, berat bayi lahir, dan TB ibu. 
Tabel 5. Analisis regresi logistik

\begin{tabular}{|c|c|c|c|c|c|c|}
\hline & Model 1 & Model 2 & Model 3 & Model 4 & Model 5 & Model 6 \\
\hline Variabel & $\begin{array}{c}\text { OR } \\
(95 \% \mathrm{Cl})\end{array}$ & $\begin{array}{c}\text { OR } \\
(95 \% \mathrm{Cl})\end{array}$ & $\begin{array}{c}\text { OR } \\
(95 \% \mathrm{Cl})\end{array}$ & $\begin{array}{c}\text { OR } \\
(95 \% \mathrm{Cl})\end{array}$ & $\begin{array}{c}\text { OR } \\
(95 \% \mathrm{Cl})\end{array}$ & $\begin{array}{c}\text { OR } \\
(95 \% \mathrm{Cl})\end{array}$ \\
\hline Riwayat asupan energi & 1,09 & 1,09 & 1,08 & 1,15 & 1,18 & 1,21 \\
\hline Kurang & $0,50-2,36$ & $0,51-2,35$ & $0,50-2,33$ & $0,53-2,49$ & $0,54-2,57$ & $0,55-2,68$ \\
\hline Cukup & 1 (ref) & 1 (ref) & 1 (ref) & 1 (ref) & 1 (ref) & 1 (ref) \\
\hline Riwayat asupan protein & 1,32 & 1,28 & 1,22 & 1,23 & 1,20 & 0,97 \\
\hline Kurang & $0,50-3,52$ & $0,48-3,41$ & $0,46-3,28$ & $0,46-3,32$ & $0,44-3,24$ & $0,35-2,69$ \\
\hline Cukup & 1 (ref) & 1 (ref) & 1 (ref) & 1 (ref) & 1 (ref) & 1 (ref) \\
\hline LILA ibu & & 0,71 & & & & 0,66 \\
\hline Kurang & & $0,39-1,29$ & & & & $0,36-1,22$ \\
\hline Normal & & 1 (ref) & & & & 1 (ref) \\
\hline Status menyusu & & & 0,66 & & & 0,65 \\
\hline Tidak diberi ASI lagi & & & $0,38-1,16$ & & & $0,36-1,17$ \\
\hline Masih diberi ASI & & & 1 (ref) & & & 1 (ref) \\
\hline Berat badan lahir & & & & $3,00^{*}$ & & 2,92 \\
\hline BBLR & & & & $1,05-8,65$ & & $0,97-8,56$ \\
\hline Normal & & & & 1 (ref) & & 1 (ref) \\
\hline Tinggi badan ibu & & & & & $2,04^{*}$ & $2,06^{*}$ \\
\hline Pendek & & & & & $1,18-3,52$ & $1,17-3,63$ \\
\hline Normal & & & & & 1 (ref) & 1 (ref) \\
\hline $\mathrm{R}^{2}(\%)$ & 0,21 & 0,68 & 0,81 & 1,56 & 2,11 & 4,44 \\
\hline Deviance & 348,60 & 347,34 & 346,52 & 343,90 & 341,96 & 333,84 \\
\hline $\mathrm{N}$ & 252 & 252 & 252 & 252 & 252 & 252 \\
\hline
\end{tabular}

* Signifikan $(p<0,05)$

\section{BAHASAN}

\section{Hubungan antara riwayat asupan energi dan protein dengan stunting}

Hasil uji (Tabel 5) menunjukkan bahwa tidak terdapat hubungan yang signifikan antara riwayat asupan energi dan protein dengan kejadian stunting $(p>0,05)$. Hal ini karena rata-rata asupan energi dan protein anak sudah tercukupi (energi $>70 \%$ AKG dan protein $>80 \%$ AKG) (Tabel 3) dan diduga pula disebabkan anak kekurangan zat gizi mikro yang juga berperan dalam proses pertumbuhan, seperti zink dan vitamin A. Vitamin A berperan dalam proses sintesis protein, sehingga berpengaruh terhadap pertumbuhan sel. Pada anak-anak yang kekurangan vitamin $A$, terjadi kegagalan pertumbuhan, sedangkan zink berperan dalam berbagai aspek metabolisme termasuk metabolisme vitamin A dan diantara tanda kekurangan zink adalah adanya gangguan pertumbuhan (18). Akan tetapi dalam penelitian ini tidak diteliti tentang zat gizi mikro, sehingga tidak dapat dilihat hubungannya dengan kejadian stunting pada anak di Kecamatan Sedayu.

Penelitian ini sejalan dengan penelitian di Kabupaten Cianjur tentang hubungan antara asupan gizi dan tinggi badan ibu dengan status gizi anak balita, yang mengemukakan bahwa tidak ada hubungan signifikan antara tingkat kecukupan energi dengan status gizi balita berdasarkan indikator TB/U (19). Hal ini juga sejalan dengan penelitian tentang karakteristik anak balita dengan status gizi akut dan kronis di perkotaan dan pedesaan di Indonesia, yang menyimpulkan bahwa variabel yang tidak berhubungan dengan status gizi kronis di perkotaan adalah konsumsi energi dan konsumsi protein, sedangkan yang berhubungan adalah pekerjaan orang tua, pendidikan orang tua, status ekonomi orang tua, dan tinggi badan orang tua (20). Hal ini sejalan pula dengan penelitian yang meneliti tentang analisis pengaruh perilaku keluarga sadar gizi terhadap stunting pada balita di Provinsi Kalimantan Barat yang menyatakan bahwa tidak terdapat hubungan antara konsumsi protein dan 
status infeksi terhadap kejadian stunting balita, namun terdapat hubungan antara perilaku KADARZI dengan stunting balita (21).

Hasil penelitian ini berbeda dengan penelitian yang dilakukan di panti sosial se-DKI dan Tangerang tentang hubungan konsumsi energi dan status gizi anak umur 6-18 bulan. Pada penelitian tersebut, anak dengan asupan energi kurang mempunyai risiko 1,7 kali menjadi gizi kurang pada indeks TB/U dan 2,2 kali pada indeks BB/U (14). Hasil penelitian di Afrika Utara juga menyimpulkan bahwa tingginya persentase stunting menunjukkan bahwa terjadi kekurangan pangan secara kronis dan dilaporkan pula bahwa terdapat defisiensi asupan gizi anak yang berupa energi dan beberapa asupan lainnya seperti kalsium, seng, selenium, yodium, niasin, vitamin B6, folat, pantotenat, biotin, vitamin C, $D$, dan $E(8)$. Sementara penelitian di Kabupaten Pati tentang prevalensi dan determinan kejadian gizi kurang pada balita mengemukakan bahwa faktor yang berhubungan dengan status gizi adalah konsumsi energi dan konsumsi protein di samping penyakit infeksi, tingkat pengetahuan, tingkat pendidikan, dan pendapatan (22). Hasil penelitian di Kabupaten Bogor juga mengemukakan bahwa asupan protein dan status gizi saat lahir mempengaruhi stunting pada anak usia 12 bulan, dikemukakan pula bahwa bayi yang lahir dari ibu dengan konsumsi protein kurang dari rata-rata pada trimester kedua mempunyai risiko 1,6 kali mengalami stunting pada usia 12 bulan (23).

\section{Determinan stunting lainnya}

Secara umum, terdapat dua faktor utama yang berpengaruh terhadap tumbuh kembang anak yaitu faktor genetik dan faktor lingkungan. Faktor genetik merupakan modal dasar dalam mencapai hasil akhir proses tumbuh kembang anak, sementara faktor lingkungan merupakan faktor yang sangat menentukan tercapai atau tidaknya potensi bawaan. Faktor lingkungan secara garis besar terdiri atas faktor lingkungan yang mempengaruhi anak pada waktu masih di dalam kandungan yang disebut faktor pranatal dan faktor lingkungan yang mempengaruhi tumbuh kembang anak setelah lahir yang disebut faktor postnatal (24).
Hasil analisis (Tabel 4) menunjukkan bahwa yang berhubungan terhadap kejadian stunting adalah berat badan lahir dan tinggi badan ibu. Hasil analisis multivariat menghasilkan variabel yang dominan berpengaruh terhadap stunting di Kecamatan Sedayu adalah TB ibu. Hasil ini sejalan dengan penelitian di Kecamatan Semarang Timur tentang faktor risiko kejadian stunting pada anak usia 2-3 tahun, yang mengemukakan bahwa tinggi badan ayah tidak terbukti menjadi faktor risiko stunting (25). Selain pendidikan ayah, TB ibu juga berhubungan dengan status stunting dari normal menjadi stunting (26), faktor genetik TB ayah tidak berhubungan dengan kejadian stunting, tetapi kejadian stunting berhubungan dengan TB ibu yang pendek (27). TB ibu dapat memprediksi kejadian stunting $(2,11 \%)$. lbu yang berpostur pendek lebih berpeluang untuk melahirkan anak yang stunting dibandingkan ibu yang berpostur normal atau dengan kata lain gen ibu punya kontribusi terhadap kejadian stunting. Meskipun faktor-faktor yang berpengaruh terhadap tinggi badan ibu tidak diteliti, namun secara sendiri maupun bersamaan variabel TB ibu berhubungan dengan kejadian stunting pada anak. Orang tua pendek dikarenakan gen dalam kromosom yang membawa sifat pendek akan berpeluang besar untuk menurunkan sifat pendek tersebut kepada anaknya. Namun demikian, jika sifat pendek orang tua disebabkan oleh nutrisi maupun patologis, maka sifat pendek tersebut tidak akan diturunkan kepada anaknya (19).

Secara umum, faktor genetik bukan sebagai penyebab utama kejadian stunting. Hal ini karena selain faktor genetik, kejadian stunting juga berhubungan dengan interaksi antara genetik dan lingkungan (27). Selain faktor genetik, faktor lingkungan pranatal dan postnatal juga berpengaruh dalam tumbuh kembang anak (24). Hasil analisis multivariat menunjukkan berat lahir anak dapat memprediksi kejadian stunting $(1,56 \%)$. Jadi terdapat hubungan antara berat bayi lahir dengan kejadian stunting. Anak yang lahir dengan berat lahir rendah umumnya terjadi karena adanya kekurangan gizi saat ibu hamil sehingga melahirkan anak BBLR dan selanjutnya tidak dapat mencapai pertumbuhan yang optimal. Efek berat lahir terhadap stunting terbesar terdapat pada usia 6 bulan awal kemudian 
menurun hingga usia 2 tahun. Apabila pada 6 bulan awal, balita dapat melakukan percepatan pertumbuhan maka ada kemungkinan balita dapat tumbuh dengan tinggi badan normal (27).

\section{KESIMPULAN DAN SARAN}

Riwayat asupan energi dan protein yang kurang bukan merupakan faktor risiko stunting pada anak usia 6-23 bulan di Kecamatan Sedayu. Faktor risiko stunting adalah berat bayi lahir dan tinggi badan ibu, sehingga disarankan bagi petugas kesehatan agar dapat mengoptimalkan perannya dalam melakukan pelayanan gizi berupa pemberian tablet Fe, pemberian makanan tambahan (PMT) ibu hamil, dan edukasi gizi terhadap pasangan usia subur (PUS) agar dapat mempersiapkan diri saat pranatal yang pada akhirnya akan mengurangi risiko kejadian berat lahir rendah. Bagi peneliti yang tertarik dengan penelitian serupa, disarankan meneliti asupan gizi mikro. Hal ini karena status gizi tidak hanya dipengaruhi oleh gizi makro tetapi terdapat beberapa jenis gizi mikro yang turut berperan dalam proses pertumbuhan anak.

\section{RUJUKAN}

1. Bappenas. Laporan pencapaian tujuan pembangunan milenium di Indonesia [Internet]. 2014 [cited 2014 Jan 20]. Available from: www. bappenas.go.id

2. London School of Hygiene and Tropical Medicine. Types of malnutrition [Internet]. 2009 [cited 2013 Jun 19]. Available from: http:// conflict.Ishtm.ac.uk

3. UNICEF. Tracking progress on child and maternal nutrition [Internet]. 2009 [cited 2013 Jun 24]. Available from: http://www.childinfo.org

4. Dewey K, Begum K. Long-term consequences of stunting in early life. Matern Child Nutr. 2011;7(3):5-18.

5. Black R, Victora C, Walker S, Bhutta Z, Christian $\mathrm{P}$, de Onis $\mathrm{M}$, et al. Maternal and child undernutrition and overweight in lowincome and middle-income countries. Lancet. 2013;382(9890):427-51.
6. Why stunting matters. Alive Thrive. A T Tech Br. 2010;2:1-7.

7. Nurlindah A. Gizi dalam siklus daur kehidupan seri baduta. Yogyakarta: Penerbit Andi; 2013.

8. Oldewage T, Dicks E, Napier C. Poverty, household food insecurity and nutrition: coping strategies in an informal settlement in the Vaal Triangle, South Africa. J Public Heal. 2006;120(9):795-804.

9. Tessema M, Belachew T, Ersino G. Feeding patterns and stunting during early childhood in rural communities of Sidama, South Ethiopia. Pan Afr Med J. 2013;14:75.

10. Nti C. Dietary diversity is associated with nutrient intakes and nutritional status of children in Ghana. AJMS. 2011;2:105-9.

11. Azwar A. Kecenderungan masalah gizi dan tantangan di masa datang [Internet]. series online. 2004 [cited 2013 Jun 28]. Available from: http://gizi.depkes.go.id

12. Kemenkes RI. Riset kesehatan dasar. Jakarta: Badan Penelitian dan Pengembangan Kesehatan Kementerian Kesehatan Rl; 2010.

13. Asrar M, Hadi H, Boediman D. Hubungan pola asuh, pola makan, asupan zat gizi dengan status gizi anak balita masyarakat Suku Naulu di Kecamatan Amahai Kabupaten Maluku Tengah Provinsi Maluku. J Gizi Klin Indones. 2009;6(2):84-94.

14. Rahmat M. Hubungan konsumsi dan status gizi anak umur 6-18 bulan di panti asuhan sosial anak se-DKI Jakarta dan Tangerang. Info Pangan dan Gizi. 2000;11(1):15.

15. Anh V, Chompikul J, Isaranurug S. Relationship between stunting and food provided to children aged from 6 to 24 months in Soc Son District, Hanoi, Vietnam. J Pub Heal Dev. 2009;7(3):4358.

16. Onis Md, Blo M, Borghi E. Prevalence and trends of stunting among pre-school children 1990-2020. Public Heal Nutr. 2011;1-7.

17. Dinas Kesehatan Kabupaten Bantul. Laporan Dinas Kesehatan Kabupaten Bantul. Bantul: Dinas Kesehatan Kabupaten Bantul; 2012.

18. Almatsier S. Prinsip dasar ilmu gizi. Jakarta: Gramedia Pustaka Utama; 2005. 
19. Hanum F, Khomsan A, Heryatno Y. Hubungan asupan gizi dan tinggi badan ibu dengan status gizi anak balita. JGIZIPANGAN. 2014;9(1):1-6.

20. Fuada N, Muljati S, Hidayat T. Karakteristik anak balita dengan status gizi akut dan kronis di perkotaan dan perdesaan, di Indonesia (RISKESDAS 2010). JEK. 2011;10(3):168-79.

21. Hariyadi D, Ekayanti I. Analisis pengaruh perilaku sadar gizi terhadap stunting di Provinsi Kalimantan Barat. J Teknol dan Kejuru. 2011;34(1):71-80.

22. Lutviani E, Budiono R. Prevalensi dan determinan kejadian gizi kurang pada balita. JKM. 2010;5(2):138-44.

23. Ernawati $F$, Rosmalina $Y$, Permanasari $Y$. Pengaruh asupan protein ibu hamil dan panjang badan bayi lahir terhadap kejadian stunting pada anak usia 12 bulan di Kabupaten Bogor. PGM. 2013;36(1):1-11.

24. Soetjiningsih. Tumbuh kembang anak. Jakarta: EGC; 2012.

25. Kusuma K, Nuryanto. Faktor resiko kejadian stunting pada anak usia 2-3 tahun (studi di Kecamatan Semarang Timur). JNC. 2012;2(4):523-30.

26. Sri L. Hubungan tinggi badan orang tua dengan perubahan status stunting dari usia 6-12 bulan ke usia 3-4 tahun. Universitas Gadjah Mada; 2011.

27. Yulidasari F. Makanan pendamping air susu ibu (MP-ASI) sebagai faktor risiko kejadian stunting pada anak usia 6-24 bulan di Kota Yogyakarta. Universitas Gadjah Mada; 2013. 